\title{
Research for Regions: Strengthening Marine Technology Transfer for Pacific Island Countries and Biodiversity beyond National Jurisdiction
}

\author{
Harriet R. Harden-Davies \\ Australian National Centre for Ocean Resources and Security, University of \\ Wollongong, Wollongong, NSW 2500, Australia
}

\begin{abstract}
Pacific Island Countries have limited capacity to engage in scientific research involving marine genetic resources in areas beyond national jurisdiction (ABNJ). Marine scientific research and capacity development are central to the regime for technology transfer established by the 1982 United Nations Convention on the Law of the Sea (LOSC), but gaps and ambiguities weaken this framework. In this article, options to strengthen scientific capacity in Pacific Island Countries, through the development of a new international legally binding instrument for the conservation and sustainable use of biodiversity in ABNJ under the LOSC, are examined. The international framework for technology transfer could be strengthened by fostering an integrated approach to the advancement, sharing and application of scientific knowledge. Coordination and collaboration at global and regional levels will be required to increase marine science cooperation, improve access to data and information, deliver training, and overcome barriers to develop institutional and individual scientific capacity.
\end{abstract}

\section{Keywords}

technology transfer - marine scientific research - capacity development - areas beyond national jurisdiction $(\mathrm{ABNJ})$ - biodiversity conservation

Acknowledgements: The author gratefully acknowledges Dr. Elizabeth Brierley for providing comments on earlier drafts of this article, and the reviewer for providing useful feedback that helped improve the article. This research has been conducted with the support of the Australian Government Research Training Program Scholarship and the University of Wollongong Global Challenges Program. 


\section{Introduction}

Marine technology transfer and capacity building are critical cross-cutting elements in the development of a new international legally binding instrument $(\text { ILBI })^{1}$ for the conservation and sustainable use of marine biological diversity in areas beyond national jurisdiction (ABNJ) under the 1982 United Nations Convention on the Law of the Sea (LOSC). ${ }^{2}$ After a decade of discussions, ${ }^{3}$ a preparatory committee (PrepCom) has been established to develop substantive recommendations on the elements of a draft text of an ILBI and report to the General Assembly by the end of 2017. The development of the ILBI is a historic turning point in the international law of the sea and seeks to address challenges facing biodiversity in the $64 \%$ of the ocean that lies in $\mathrm{ABNJ}$, through: environmental impact assessments, area-based management measures, benefit sharing of marine genetic resources, and capacity building and technology transfer.

Scientific capacity development and technology transfer are crucial for the conservation and sustainable use of biodiversity in ABNJ; this has been recognised at the PrepCom. ${ }^{4}$ The need to strengthen national and regional capabilities in marine science and technology to enable developing countries to share in marine scientific advances, and absorb and apply technology and scientific knowledge, has long been recognised. A resolution from the Final Act to the Third United Nations Conference on the Law of the Sea (UNCLOS III) stated

1 United Nations General Assembly Resolution 69/292 'Development of an international legally binding instrument under the United Nations Convention on the Law of the Sea on the conservation and sustainable use of marine biological diversity of areas beyond national jurisdiction'. 6 July 2015. Available at https://daccess-ods.un.org/TMP/1859741.2109375.html; accessed 10 September 2017.

2 United Nations Convention on the Law of the Sea, (Montego Bay, 10 December 1982, in force 16 November 1994) 1833 UNTS 396.

3 E Druel, J Rochette, R Billé and C Chiarolla, 'A long and winding road. International discussions on the governance of marine biodiversity in areas beyond national jurisdiction', IDDRI Study 07/13 (IDDRI, Paris, 2012); G Wright, J Rochette, E Druel and K Gjerde, 'The long and winding road continues: Towards a new agreement on high seas governance' IDDRI Study 01/16 (IDDRI, Paris, 2015).

4 R Long and M Rodriguez Chaves, 'Anatomy of a new international instrument for marine biodiversity beyond national jurisdiction. First impressions of the preparatory process' (2015) 6 Environmental Liability - Law, Policy and Practice 213-229; IISD Reporting Services. Earth Negotiations Bulletin. Summary of the Second Session of the Preparatory Committee on Marine Biodiversity Beyond Areas of National Jurisdiction: 26 August-9 September 2016. Vol 25. No. 118. Available at http://enb.iisd.org/oceans/bbnj/prepcom2/; accessed 11 September 2017. 
that unless urgent measures were taken, the "scientific and technological gap between developed and developing States would widen further" and "endanger the very foundations of the LOSC regime". Equitability is integral to the LOSC regime for technology transfer. ${ }^{6}$ Capacity development and technology transfer, have been described as the 'equitable ingredients' of the ILBI, important for both intra-generational and inter-generational equity, ${ }^{7}$ especially for Small Island Developing States (sIDs). ${ }^{8}$ The importance of technology transfer and scientific capacity development to implement the LOSC and benefit from sustainable development has been recognised by the United Nations General Assembly (UNGA). ${ }^{9}$ Sustainable Development Goal 14a calls on States to increase scientific knowledge, develop research capacity and transfer marine technology to improve ocean health and to enhance the contribution of marine biodiversity to the development of developing countries, particularly for sids. ${ }^{10}$

'Resolution on the development of national marine science, technology and ocean service infrastructures'. Adopted by the Conference at the 182nd meeting on 30 April 1982. Third United Nations Conference on the Law of the Sea 1973-1982, Concluded at Montego Bay, Jamaica on 10 December 1982. A/CONF.62/120. Available at http://legal.un.org/diplomatic conferences/1973_los/docs/english/vol_16/a_conf62_120.pdf; accessed 10 September 2017. LOSC Preamble; LOsC Art. 266(3) calls for the creation of favorable economic and legal conditions for the transfer of marine technology on an equitable basis.

For example, equitable sharing of benefits of marine genetic resources from ABNJ could be considered as intra-generational equity, and the conservation and sustainable use of biological diversity for future generations could be considered as inter-generational equity.

8 See, for example, "Supplementary view of the Government of the Federated States of Micronesia on the elements of a draft text of an international legally binding instrument under the United Nations Convention on the Law of the Sea on the conservation and sustainable; use of marine biological diversity of areas beyond national jurisdiction following the conclusion of PrepCom 2". Available at http://www.un.org/depts/los/biodiversity/ prepcom_files/rolling_comp/Federated_States_of_Micronesia.pdf; accessed 14 February 2017, at pp. 1-2.

United Nations General Assembly Resolution 71/257 'Oceans and Law of the Sea'. 23 December 2016. at Preamble and para 13, available at https://documents-dds-ny.un.org/doc/UNDOC/ GEN/N16/466/62/PDF/N1646662.pdf?OpenElement accessed 10 September 2017; United Nations General Assembly Resolution 70/235 'Oceans and Law of the Sea' 23 December 2015. at Preamble., available at https://documents-dds-ny.un.org/doc/UNDOC/GEN/ N15/456/94/PDF/N1545694.pdf?OpenElement; accessed 10 September 2017.

Sustainable Development Goal 14 "Conserve and sustainably use the oceans, seas and marine resources for sustainable development”. In: United Nations General Assembly Resolution 70/1 'Transforming our world: the 2030 Agenda for Sustainable Development', 
SIDS face capacity constraints which hinder their ability to participate in and benefit from scientific research in $\mathrm{ABNJ},{ }^{11}$ as highlighted by the Alliance of Small Island Developing States (AOSIS) and Pacific Small Island Developing States (PSIDS) at the PrepCom. ${ }^{12}$ The Federated States of Micronesia has suggested that the ILBI should include measures for the acquisition of scientific knowledge relating to biodiversity in $\mathrm{ABNJ}$ and training in marine science and technology. ${ }^{13}$ The Group of 77 (G77) plus China have stated that the IL BI should promote increased scientific knowledge, research capacity development and marine technology transfer. ${ }^{14}$ One of the key challenges facing States in the development of the ILBI is to enhance the implementation of LOSC Part XIV (Development and Transfer of Marine Technology) to enable equitable participation in the conservation and sustainable use of biodiversity in $\mathrm{ABNJ}$, without undermining existing regional frameworks. ${ }^{15}$

In this article, options are examined to strengthen marine technology transfer and scientific capacity development for Pacific Island Countries to benefit from marine genetic resources in ABNJ under an ILBI. First, the LOSC regime

25 September 2015, at p. 14; available at http://www.un.org/en/ga/search/view_doc.asp? symbol=A/RES/70/1; accessed 1o September 2017.

11 C Salpin, V Onwuasoanya, M Bourrel and A Swaddling, 'Marine Scientific Research in Pacific Small Island Developing States' (2016) Marine Policy, online, https://doi.org/10.1016/ j.marpol.2016.07.019HY.

12 "Alliance of Small Island States (AOSIS) Submission on Capacity Building and Transfer of technology at the Second Session of the Preparatory Committee on the Development of an International Legally Binding Instrument under the United Nations Convention on the Law of the Sea on the Conservation and Sustainable Use of Marine Biological Diversity". 5 December 2016. Available at http://www.un.org/depts/los/biodiversity/ prepcom_files/rolling_comp/Aosis-capacity_building_and_transfer_of_technology .pdf; accessed 14 February 2017; "PSIDS Submission on Institutional Arrangement. BBNJ Preparatory Committee”. 5 December 2016. Available at http://www.un.org/depts/los/ biodiversity/prepcom_files/rolling_comp/Ps ID S-institutional_arrangements.pdf; accessed 14 February 2017.

13 FSM (n 8).

14 G77, "Development of an internationally legally binding instrument under the United Nations Convention on the Law of the Sea on the conservation and sustainable use of marine biological diversity of areas beyond national jurisdiction (A/RES/69/292) Group of 77 and China's Written Submission. 5 December 2016" available at: http://www .un.org/depts/los/biodiversity/prepcom_files/rolling_comp/Group_of_77_and_China .pdf; accessed 14 February 2017.

15 UNGA Resolution 69/292 states that the development of the ILBI "should not undermine existing relevant legal instrument and frameworks and relevant global, regional and sectoral bodies", UNGA (n 1) at para 3. 
for technology transfer is examined, illustrating the linkages between scientific research, capacity development and knowledge exchange. Second, the opportunities and challenges facing Pacific Island Countries to access and use marine genetic resources in $\mathrm{ABNJ}$ are discussed, highlighting technology transfer and capacity development needs. Third, options to strengthen the implementation of the LOSC framework provisions for technology transfer and scientific capacity development under an ILBI, through the generation, sharing and application of scientific knowledge, are identified. The article concludes that development of an ILBI is an opportunity to strengthen the international framework for technology transfer and scientific capacity development, but resource and coordination challenges need to be overcome.

\section{International Legal Framework for Marine Technology Transfer}

The purposes of technology transfer identified in the LOSC range from social and economic development ${ }^{16}$ to the protection and preservation of the marine environment. ${ }^{17}$ The framework established by the LOsC for the development and transfer of marine technology ${ }^{18}$ is strongly interlinked with scientific capacity development. For example, increasing scientific capacity is identified in Article 266(2) as an aim of technology transfer, and the development of technological infrastructure and human resources (through training and education) are among the basic objectives of technology transfer articulated in LOsC Article 268. ${ }^{19}$ Technical, human and institutional scientific capacity development provisions in the LOSC include: the acquisition of technological infrastructure, ${ }^{20}$ development of human resources through training and education, ${ }^{21}$ and the establishment of national and regional marine science and technology centres. ${ }^{22}$

The acquisition, evaluation and dissemination of marine scientific and technological knowledge, information and data are emphasised in the LosC

\footnotetext{
16 LOsC Art. 266.

17 LOSC Art. 202.

18 LOsC Parts XIV (development and transfer of marine technology), XIII (marine scientific research), and XI (the Area).

19 Losc Arts. 268(c) and (d).

20 LOsC Art. 268(c).

21 LOsC Arts. 275(2), 277(a), 268(d).

22 LOsC Arts. 274-277.
} 
as a basic objective ${ }^{23}$ and modality of technology transfer. ${ }^{24}$ It is also an obligation for marine scientific research; ${ }^{25}$ Article 244 of the LOSC provides that States shall publish and disseminate knowledge resulting from marine scientific research and promote the flow of scientific data and information, especially to developing States. Article 244 further provides that States shall strengthen the autonomous marine scientific research capabilities of developing States, including through technical and scientific training programmes. Sharing the outcomes of marine scientific research, and building capacity to assist developing States to make use of those outcomes, are therefore obligations for the conduct of research in $\mathrm{ABNJ}$, whether exercising the freedom of marine scientific research in the high seas ${ }^{26}$ and/or fulfilling the duty to conduct marine scientific research in the Area for the benefit of mankind. ${ }^{27}$

However, there are gaps, weaknesses and ambiguities in LOSC Part XIV that constrain effective implementation. Despite the various objectives and measures of technology transfer described in Part XIV, the LOSC does not include a definition of "technology" or "technology transfer". Absent or unclear institutional and funding mechanisms render many provisions of Part XIV little more than weak inducements for States. This also creates challenges to monitor or evaluate technology transfer. The provisions of Part XIV are somewhat ambiguous given the requirement that technology transfer should be conducted on reasonable, fair and equitable ${ }^{28}$ terms to States that "need and request" it. ${ }^{29}$ International cooperation in marine scientific research (facilitated through scientist exchanges and conferences), ${ }^{30}$ especially at the regional and subregional level, ${ }^{31}$ is the primary method to achieve technology transfer identified by the LOSC. ${ }^{32}$ As a result, the implementation of the LOSC regime for the development and transfer of marine technology, including scientific capacity

23 Losc Art. 268(a).

24 LOSC Art. 277(f) identifies "prompt dissemination of results of marine scientific and technological research in readily available publications” as a function of regional [marine science and technology] centres.

25 All States have the right to conduct marine scientific research (LOSC Arts. 87, 143, 238), subject to responsibilities. For example, Losc Art. 240 elaborates principles for the conduct of marine scientific research.

26 LOsC Art. 87(1)(f).

27 LOSC Art. 143(1).

28 Losc Arts. 266(1), 269(b).

29 LOsC Arts. 266 and 275.

$30 \quad$ Losc Art. 269, 277(d).

31 Losc Art. 268(e).

32 LOSC Arts. 266(1), 268(e), 269(a), 270, 272, 273, 278. 
development, is a main focus in the development of the ILBI. The example of marine genetic resources ${ }^{33}$ in Pacific Island Countries illustrates the practical challenges and opportunities for strengthening the implementation of technology transfer under the ILBI.

\section{Marine Genetic Resources Beyond National Jurisdiction: Opportunities and Challenges for Technology Transfer in Pacific Island Countries}

The high marine biodiversity of the South-West Pacific region encompasses rich genetic and biochemical diversity, ${ }^{34}$ making the region a significant source of marine genetic resources and target for marine bio-discovery activities. The South-West Pacific was a major source of natural products from invertebrates in the 1990s. ${ }^{35}$ Although this has mainly been in shallow coastal waters, the growing number of deep-sea natural products ${ }^{36}$ described from the region indicates some level of research activity in deep-sea marine genetic resources. Examples of deep-sea natural products derived from the Pacific include: compounds with anti-cancer properties derived from sponges collected in Guam and Palau and from fungal strains collected off Fiji; and sterols with anti-fungal properties from a starfish collected off New Caledonia. ${ }^{37}$ Marine genetic resources patents associated with the North Fiji Basin, Manus Basin,

33 "Marine genetic resources" are not defined in the Losc, but could be considered to include material from marine animals, plants, microbes or other organisms, and parts thereof containing functional units of heredity of actual or potential value. For discussions on the definition of marine genetic resources. See for example: M Vierros, C Suttle, H Harden-Davies and G Burton, 'Who Owns the Ocean? Policy Issues Surrounding Marine Genetic Resources' (2016) 25(2) Limnology and Oceanography Bulletin 29-35; H Harden-Davies, 'Deep-Sea Genetic Resources: New Frontiers for Science and Stewardship in Areas Beyond National Jurisdiction' (2017) 137 Deep Sea Research Part II: Topical Studies in Oceanography 504-513.

TF Molinski, DS Dalisay, SL Lievens and JP Saludes, 'Drug Development from Marine Natural Products' (2009) 8(1) Nature Reviews. Drug Discovery 69-85.

35 MC Leal, J Puga, J Serodio, NCM Gomes and R Calado, 'Trends in the Discovery of New Marine Natural Products from Invertebrates over the Last Two Decades-Where and What Are We Bioprospecting?' (2012) 7(1) PLoS ONE e30580.

36 D Skropeta, 'Deep-Sea Natural Products' (2008) 25(6) Natural Product Reports 1131-1166; D Skropeta and L Wei, 'Recent Advances in Deep-Sea Natural Products' (2014) 31(8) Natural Product Reports 999-1025.

Skropeta and Wei (n 36$)$. 
Tonga Trench and Kermadec Trench. ${ }^{38}$ Nevertheless, the South-West Pacific deep sea remains one of the most under-sampled areas of the global ocean, leaving significant gaps in knowledge of its deep-sea biodiversity. ${ }^{39}$ Increased scientific research would be necessary to access, use and derive benefits from marine genetic resources in South-West Pacific ABNJ. ${ }^{40}$

The financial and technological requirements of undertaking research in ABNJ are, however, beyond the capacity of Pacific Island Countries alone. Low population, large geographic area, remoteness, and limited human, financial, technical and scientific resources pose significant obstacles to the research capacity of Pacific Island Countries. ${ }^{41}$ Limited scientific and technological capacity, such as a lack of offshore ocean research vessels and sampling equipment $t^{42}$ and of onshore laboratory equipment and information technology infrastructure, constrains the capacity of Pacific Island Countries to access, use or benefit from marine genetic resources in ABNJ. ${ }^{43}$ Pacific Island coun-

38 P Oldham, S Hall, C Barnes, C Oldham, M Cutter, N Burns and L Kindess, 'Valuing the Deep: Marine Genetic Resources in Areas Beyond National Jurisdiction' (One World Analytics, London, 2014) 1-241, at pp. 81, 82, 143, 158.

39 C R German, E Ramirez-Llodra, MC Baker, PA Tyler and the ChEss Scientific Steering Committee, 'Deep-Water Chemosynthetic Ecosystem Research During the Census of Marine Life Decade and Beyond: A Proposed Deep-Ocean Road Map' (2011) 6(8) PLoS ONE 1-16.

40 Data, technology transfer, knowledge and capacity development are examples of 'nonmonetary' benefits from marine genetic resources, Harden-Davies (n 32).; The UNGA has recognised the importance of research on marine genetic resources for the "purpose of enhancing scientific understanding, potential use and application and enhanced management of marine ecosystems", UNGA Resolution 71/257. 'Oceans and Law of the Sea'. 23 December 2016 at para 246; available at https://documents-dds-ny.un.org/doc/UNDOC/ GEN/N16/466/62/PDF/N1646662.pdf?OpenElement; accessed 10 September 2017.

41 Salpin (n 11) observed that the challenges facing Pacific sids to participate in, and fully benefit from, marine scientific research include: lack of research infrastructure; limited education opportunities and expertise; and limited funding. See also: RJ Morrison, J Zhang, ER Urban Jr, J Hall, V Ittekkot, B Avril, L Hu, GH Hong, S Kidwai, CB Lange, V Lobanov, J Machiwa, ML San Diego-McGlone, T Oguz, FG Plumley, T Yeemin, W Zhu and F Zuo, 'Developing Human Capital for Successful Implementation of International Marine Scientific Research Projects' (2013) 77(1-2) Marine Pollution Bulletin 11-22.

42 Salpin (n 11).

43 P Bernal and A Simcock, 'Marine Scientific Research' in L Inniss and A Simcock (eds), The First Global Integrated Marine Assessment: World Ocean Assessment I (United Nations, New York, 2016) at p. 18; SK Juniper, 'Technological, Environmental, Social and Economic Aspects. Information Paper 3 ' in IUCN Information Papers for the Intersessional Workshop on Marine Genetic Resources 2-3 May 2013, United Nations General Assembly Ad Hoc Open-Ended Informal Working Group to Study Issues Relating to the Conservation and 
tries are therefore reliant upon foreign research institutions, resources and expertise to access and use marine genetic resources from ABNJ. Technology transfer and scientific capacity development would therefore be needed for Pacific Island Countries to engage in, and benefit equitably from, marine genetic resources in $\mathrm{ABNJ}$.

\section{Technology Transfer}

According to the Intergovernmental Oceanographic Commission (IOC) Criteria and Guidelines on the Transfer of Marine Technology (сGтмт) ${ }^{44}$ marine technology includes:

- Information and data (marine sciences, operations and services);

- Expertise, knowledge, skills, methods (technical/scientific/legal);

- Equipment (in situ sampling and observation, laboratory analysis and experimentation);

- Computer software, models and modelling techniques;

- Manuals, guidelines, criteria, standards, reference materials.

The IOC CGTMT have been acknowledged by many States as a useful tool in the development of the ILBI, ${ }^{45}$ although the $\mathrm{G}_{77}$ plus China suggest ${ }^{46}$ that further elaboration of the guidelines would be useful. A wide range of technology could be included in the scope of marine genetic resources in ABNJ. This could include scientific research hardware such as at-sea observation and sampling equipment, on-shore laboratory equipment, and data management and analysis software (e.g., for biodiversity and climate change modelling, oceanography and sea-bed mapping). Information sharing could also include manuals and guidelines for the collection, storage and curation of biological samples.

Sustainable Use of Marine Biological Diversity Beyond Areas of National Jurisdiction. (IUCN Environmental Law Centre, Bonn, 2013) at p. 15.

44 Intergovernmental Oceanographic Commission (IOC), 'IOC Criteria and Guidelines on the Transfer of Marine Technology'. IOC Information Document 1203 (IOC-UNESCO, Paris, 2005), para A.2 at p. 9.

45 See for example: "Development of an International Legally-Binding Instrument under UNCLOS on the Conservation and Sustainable Use of Marine Biological Diversity of Areas Beyond National Jurisdiction (BBNJ Process). Written Submission of the EU and its Member States. Capacity Building and Transfer of Marine Technology. 31 January 2017" at para 17. Available at http://www.un.org/depts/los/biodiversity/prepcom_files/ rolling_comp/EU_Capacity-Building_and_Transfer_of_Marine_Technology.pdf; accessed 16 February 2017; AOSIS (n5).

$46 \quad \mathrm{G}_{77}\left(\mathrm{n}_{14}\right)$, at p. 5 , para 8. 
Technologies that can be applied for multiple purposes could be particularly important for capacity development. The merits of multi-use technologies are illustrated by the Centre of Drug Discovery and Conservation of the University of the South Pacific, which has a dual focus on marine biodiscovery and ecological surveys. For example, 'shot-gun DNA sequencing' could be used for marine biodiscovery research as well as other purposes, such as water quality monitoring. Low technology, low-key and long-term approaches to technology transfer and capacity development are often more effective in Pacific Island Countries than short-term, high-technology approaches. ${ }^{47}$ For technology transfer to be useful in the long term requires considerations of issues such as the cost of maintenance and operation.

Data and knowledge are forms of technology, access to data and knowledge is a form of technology transfer. ${ }^{48}$ Access to data is also a regional priority identified in the Pacific Islands Regional Ocean Policy. ${ }^{49}$ Data and information on marine biodiversity, natural products and genetics, as well as biological samples collected from ABNJ, could enable Pacific Island Countries to benefit from marine genetic resources. However, the usefulness of access to data, knowledge and samples is largely dependent on scientific and technological capacity, including skilled personnel, scientific equipment, and technical infrastructure, such as computers and reliable internet access. ${ }^{50}$ Information communication technology limitations have been highlighted by Pacific Island Countries at the PrepCom. ${ }^{51}$

Information technology could therefore be particularly important to enable Pacific Island Countries to access data and information relating to ABNJ.

47 See, for example, C Kaluwin and A Smith, 'Coastal vulnerability and integrated coastal zone management in the Pacific Island region' (1997) 24Journal of Coastal Research 95-106. IOC (n 43); Harriet Harden-Davies, 'Marine Science and Technology Transfer: Can the Intergovernmental Oceanographic Commission Advance Governance of Biodiversity Beyond National Jurisdiction?' (2016) 74 Marine Policy 26o-267; see also Losc Art. 277(e).

49 Pacific Island Forum Secretariat (2002) 'Forum Communiqué: Annex 2 Pacific Island Regional Ocean Policy', Fiji: 33rd Pacific Islands Forum (15-17 August 2002). Theme 2. Available at http://www.forumsec.org/resources/uploads/attachments/documents/ PIROP.pdf; accessed 1o September 2017.

Salpin (n 11) observed that the "value and use of research results and data is [sic] largely correlated to the suitability of data management systems, as well as expertise of local scientists-lack of adequate handling and storage, processing technology and expertise has been an obstacle to fully benefiting from marine scientific research results, data and samples".

$51 \quad$ PSIDS (n 12). 
Various existing data-sharing mechanisms are in operation at regional ${ }^{52}$ and global ${ }^{53}$ levels that could be relevant. However, resource constraints, limited funding and overlapping functions can impede the efficiency of data management systems in the region. For example, the Pacific Island Marine Portal ${ }^{54}$ was established as a collaborative project between the Pacific Islands Marine Resources Information System (PIMRIS) and the IOC International Oceanographic Data and Information Exchange (IODE) to improve access to Pacific marine information for the Pacific Islands community. However, although some regional organisations appear to be using the portal to share information, resource constraints inhibit its effectiveness. This illustrates the importance of coordination and sustained resourcing for data management systems at regional and global levels.

\section{Scientific Capacity Development}

\section{International}

International organisations, such as the International Seabed Authority, Food and Agriculture Organization, and the IOC are involved in facilitating capacity development in the region. The IOC is recognised in the LOSC as a competent international organisation for marine scientific research. ${ }^{55}$ The IOC offers a forum for Pacific Island Countries to seek support for marine science capacity development and technology transfer, and the IOc sids Action Plan ${ }^{56}$ provides a renewed impetus for IOC's 148 Member States to support marine science capacity development and technology transfer. It also has a role in implementing the sids Accelerated Modalities of Action (SAMOA) Pathway. ${ }^{57}$ Eleven Pacific

$5^{2}$ For example: Enhancing Pacific Ocean Governance project (EPOG), http://msp.csiro.au/; accessed 15 February 2017; PacGeo, available at www.pacgeo.org; accessed 15 February 2017.

53 For example: IOC International Oceanographic Data and Information Exchange (IODE), Ocean Biogeographic Information System (OBIS), available at www.iobis.org; accessed 20/02/017.

54 Available at http://www.pimrisportal.org/about; accessed 20 October 2016. See also J Veitayaki, GR South, 'Capacity building in the marine sector in the Pacific Islands: The role of the University of the South Pacific's Marine Studies Programme' (2001) 25 Marine Policy 437-444.

$55 \quad$ LOSC Annex VIII, Article 2(2).

56 IOC, 2016. IOC SIDS Action Plan: A follow-up to the Small Island Developing States SAMOA Pathway Outcome Document. Item 4.1.2., 49th Session of Executive Council, Unesco, Paris, 7-10 June 2016. IOc/EC-XLIX/2 Annex 5. Available at http://unesdoc.unesco.org/ images/0024/o02449/244941e.pdf; accessed og September 2017. ment for sids, including enhancing oceanographic research capacity. Small Island 
Island Countries are Member States of Ioc. ${ }^{58}$ Increasing the participation of Pacific Island Countries in IOC could help promote regional capacity development priorities at the international level. However, resource constraints limit Ioc's activities in Pacific Island Countries. The Ioc Capacity Development fund (which sources contributions for projects ranging from monitoring ocean acidification impacts to tsunami preparedness) is dependent on voluntary Member State contributions.

The IOC regional Sub-Commission for the Western Pacific (IOC-WESTPAC), established in 1989 and hosted by the Government of Thailand since 1994, has a mandate to promote and coordinate international cooperation in marine scientific research and capacity development in the region. IOC-WESTPAC capacity development ${ }^{59}$ activities include: training courses and summer schools; and international scientific symposia held every three years with associated young scientist awards, travel grants and internship programs. The IOC Regional Network of Training and Research Centres on Marine Science (RTRCs) was established in 2008 to improve regional capacity on marine science, ${ }^{60}$ recognising the "disparity in capacity and capability among the Member States of the region, and high capability of several Member States in marine science, ocean

Developing States Accelerated Modalities of Action (samoA Pathway). Report of the third International Conference on Small Island Developing States, Apia, Samoa, 1-4 September 2014. A/CONF.233/10. At Annex paras 58a and 68f. Available at http://www.un.org/ga/ search/view_doc.asp?symbol=A/RES/69/15\&Lang=E; accessed 10 September 2017.; IOC Decision EC-XLIX, Dec. 4.1(II) 'IOC Contribution towards Agenda 2030: IOC sids Action Plan' at p. 16; available at http://unesdoc.unesco.org/images/oo24/o02449/244991e.pdf; accessed 10 September 2017.

$5^{8}$ Nauru, Cook Islands, Fiji, Vanuatu, Tuvalu, Tonga, Solomon Islands, Samoa, Papua New Guinea, Palau, Niue.

59 IOC-Westpac 'Westpac Approach to Capacity Development in Marine Science'. (IOCWESTPAC, Bangkok, 2014) 1-10. Available at http://iocwestpac.org/online\%2odoc/ Capacity\%20Development.pdf; accessed 11 September 2017.

6o The RTRC initiative was adopted by the Sub-Commission at its Seventh Intergovernmental Session (WestPaC-VII, 26-29 May 2008, Sabah, Malaysia, http://unesdoc.unesco.org/ images/o021/002185/218502e.pdf; accessed 10 September 2017) and endorsed by the IOC at its forty-first session of the Executive Council (24 June-1 July 2008, Paris, France, http://unesdoc.unesco.org/images/oo17/oo1798/179861e.pdf; accessed 10 September 2017). The first RTRC was established at the First Institute of Oceanography, State Oceanic Administration of China (FIO, SOA) with a focus on ocean dynamics, climate change and modelling. Discussions with other RTRCs are ongoing with Indonesia, Thailand, Malaysia and Vietnam. Available at http://iocwestpac.org/capacity-development/49.html; accessed 26 September 2016. 
observations and services". ${ }^{61}$ However, only three Pacific Island Countries ${ }^{62}$ are IOC-WESTPAC Member States. ${ }^{63}$ Most of the activities of IOC-WESTPAC take place in South-East Asia. Resource constraints limit the implementation of IOC-WESTPAC activities. IOC-WESTPAC has expressed "deep concern over the long-time overloaded and unstable staffing situation at the WESTPAC Office".64 IOC-WESTPAC has requested assistance from IOC Member States to implement regional capacity-building activities, including the RTRC, by encouraging Member States, donors, organizations, and institutions to engage in the regional network. ${ }^{65}$ To date, IOC-WESTPAC has not been active in capacity-development activities in Pacific Islands. Increasing the participation of Pacific Island Countries in IOC-WESTPAC could elevate Pacific Island engagement in regional IOC capacity-development and technology-transfer activities. However, this would be largely reliant on enhanced resources and coordination.

In practice, capacity development in the region is supported through multilateral and bilateral arrangements with donor countries, or through ad-hoc international research collaborations. For example, the University of the South Pacific (USP) Centre of Drug Discovery and Conservation has been the recipient of three consecutive International Cooperative Biodiversity Grants from the Us National Institutes of Health $\left(2005^{-2018}\right)$ in a consortium with the Georgia Institute of Technology and Scripps Institute of Oceanography, aiming to support sustained international research engagement in the SouthWest Pacific. Another example, the memorandum of understanding between the Republic of Korea Institute of Ocean Science and Technology (KIOST) and the Secretariat of the Pacific Community (SPC), illustrates how bilateral links aim to support sustainable Pacific development through science and technical innovation, including through technical meetings, joint lectures, exchange

61 IOC-WESTPAC. UNESCO-IOC Regional Network of Training and Research Centres in the Western Pacific. 7th Intergovernmental Session of the IOc Sub-Commission for the Western Pacific, Sabah, Malaysia, 26-29 May 2008. un doc IOC/SC-WESTPAC-VII/3s. Annex II, at p. 3; http://iocwestpac.org/file/1641/ref/Adopted\%2oGuideline\%20and\%20 Procedure.pdf; accessed 26 September 2016.

62 Samoa, Solomon Islands, Tonga.

63 There are 22 IOC-WEStPAC Member States, including USA, UK, France, Australia, New Zealand.

64 IOC. Tenth Intergovernmental Session of the IOc Sub-Commission for the Western Pacific (WESTPAC-X). Bangkok, 25 May 2015. IOC/SC-WESTPAC-X/3s, at paras 4 and 5; available at http://unesdoc.unesco.org/images/0023/002341/234134E.pdf; accessed 10 September 2017.

65 IOC-WESTPAC (n 62). 
initiatives, sharing samples and instrumentation. ${ }^{66}$ Strengthening and enhancing these types of collaborations and capacity-development initiatives would be crucial to ensure long-term meaningful technology transfer to Pacific Island Countries and equitable participation in the implementation of an ILBI.

\section{Institutional}

Few Pacific Island Countries have established marine scientific research institutions. ${ }^{67}$ Scientific research capacity in the South-West Pacific region is largely concentrated in regional organisations and institutions. For example, the USP, established in 1968, is a regional university jointly owned by the governments of twelve member countries. ${ }^{68}$ The main campus is in Fiji, the School of Agriculture and Food Technology is in Samoa, the School of Law is in Vanuatu and there are campuses in all member countries. ${ }^{69}$ USP is a regional hub for international marine research collaborations, provides education and training, and represents all Pacific Island Countries in the International Council for Science (a role usually reserved for Learned Academies)..$^{70}$ The USP marine studies program, established in 1978 , has relied on foreign donor programs, as well as on funding from USP member countries, ${ }^{71}$ highlighting the challenges facing the region to secure human, financial and infrastructure resources. The USP's ‘Centre of Drug Discovery and Conservation’ of the Institute for Applied Science has some research infrastructure for genetic resources research; however, research capacity remains limited and USP is not currently capable of undertaking research in ABNJ.

66 Convention for the Protection of the Natural Resources and Environment of the South Pacific Region (Nouméa Convention) (Nouméa, 24 November 1986, in force 22 August 1990) PITSE 15; see also United Nations General Assembly Resolution 70/235 'Oceans and Law of the Sea' 23 December 2015. at Preamble, available at https://documentsdds-ny.un.org/doc/UND OC/GEN/N15/456/94/PDF/N1545694.pdf?OpenElement; accessed 10 September 2017, at para 248.

67 Salpin (n 11).

68 Cook Islands, Fiji, Kiribati, Marshall Islands, Nauru, Niue, Solomon Islands, Tokelau, Tonga, Tuvalu, Vanuatu and Samoa.

69 USP's mission includes tertiary education and the application of research to deliver benefits and solutions to communities and countries in the Pacific region. Available at https:// www.usp.ac.fj/index.php?id=usp_introduction; accessed 6 July 2016.

70 Of the 121 Members of the International Council for Science, USP is the only Member that is a university that represents multiple countries. Available at http://www.icsu.org/asiapacific/about-icsu-roap/asia-pacific-members; accessed 4 July 2016.

71 Veitayaki and South (n 54$)$. 
Other regional organisations could play a role in technology transfer and capacity development. For example, the SPC is the regional scientific and technical organisation, it has a role to facilitate international cooperation in scientific research and deliver scientific and technical services (including conservation, deep sea minerals, maritime boundary delimitation and genetic resources). ${ }^{72}$ The South Pacific Regional Environment Program (SPREP) in Samoa also has involvement in marine scientific research, including as the regional point of contact for the Pacific regional alliance for the Global Ocean Observing System (PI-GOOS). ${ }^{73}$

The establishment of national and regional marine science and technology centres is promoted in the LOSC to advance the conduct of marine scientific research, enhance capabilities to utilise and preserve marine resources and transfer marine technology. ${ }^{74}$ The UNGA has recognised the importance of coordinating activities with regional and national marine science and technology centres to achieve development objectives, ${ }^{75}$ and the SAMOA Pathway has highlighted the "establishment of dedicated regional oceanographic centres" and the provision of technical assistance. ${ }^{76}$

Existing marine science and technology institutions in the region, such as USP, fit the criteria of 'regional marine science and technology centres' referred to in LOSC Article 277, such as for education and data exchange. These regional marine science and technology centres function as a decentralised but interconnected network, illustrating that a network model could be more appropriate for sids than individual centres.

Coordination is critically important for effective ocean governance in the region. ${ }^{77}$ Therefore, in addition to strengthening the capacity of individual

72 Pacific Community, 2016, 'Pacific Community Strategic Plan 2016-2020'. Pacific Community, Nouméa, pp. 5-7. Available at http://www.spc.int/images/publications/en/Cor porate/Strategic-Plan-2016-2020.pdf. Accessed 30 October 2016.

PI-GOOS is a long-term sustained scientific cooperation program between SPREP, USA and Australia to monitor the Pacific Ocean, as part of the Global Ocean Observing System; http://www.goosocean.org/index.php?option=com_content\&view=article\&id=40\&Ite $\mathrm{mid}=140$. Accessed 30 June 2017 .

$74 \quad$ LOSC Arts. 269, 274, 277.

75 UNGA Res 70/235 (n 9) at [249].

76 samoA Pathway (n 55$)$ at [58.f].

77 See for example: E Druel, P Ricard, J Rochette and C Martinez, Governance of Marine Biodiversity in Areas Beyond National Jurisdiction at the Regional Level: Filling the Gaps and Strengthening the Framework for Action.Case Studies from the North-East Atlantic, Southern Ocean, Western Indian Ocean, South West Pacific and the Sargasso Sea, Study 4/12 (IDDRI, Paris, 2012); A Wright, N Stacey and P Holland, 'The Cooperative Framework 
institutions, increasing links between organisations (inside and outside the region) is important to avoid duplication of activities and enhance the existing network of marine science and technology centres. The coordination and delivery of technology transfer and capacity development initiatives, however, will depend on the availability of resources, as highlighted by Pacific sids. ${ }^{78}$

\section{Individual}

For Pacific Island Countries to make use of marine genetic resources in $\mathrm{ABNJ}$, training and skill development could be required in disciplines such as taxonomy, ecology, genetics, molecular biology, microbiology, chemistry, oceanography and bio-informatics. ${ }^{79}$ Participation in research cruises in the region could provide an opportunity for research training and access to in situ marine genetic resources. Research collaborations and post-cruise mentoring could enhance research training opportunities for Pacific Island Countries. Training in 'on-shore' research skills could be more useful than 'at-sea' skills, given the technological limitations in the region.

A flexible and adaptable approach is necessary to provide training opportunities that are fit for the needs of the region..$^{80}$ USP, for example, offers shortterm training opportunities, such as workshops, as well as long-term academic education programs (pre-degree, undergraduate and post-graduate) in various marine scientific research disciplines. Distance learning enables participation across different Pacific Island countries; for example, more than half the students at USP use distance learning. ${ }^{81}$ Information technology infrastructure is required to enable distance-learning opportunities and support knowledge diffusion across the region. International research collaboration links and access to academic experts could help address gaps in expertise and develop human capacity in the region. ${ }^{82}$

for Ocean and Coastal Management in the Pacific Islands: Effectiveness, Constraints and Future Direction' (2006) 49(9-10) Ocean \& Coastal Management 739-763.

78 PSids (n 12 ).

79 Note: LOSC Art. 277(a) refers to training and educational programmes across a number of disciplines relating to marine scientific and technological research, including marine biology, conservation and management of living resources, oceanography, hydrography, engineering, geological exploration of the seabed, mining and desalination technologies.

8o J Veitayaki and PE Manoa, 'Building Capacity in the Marine Sector in the Pacific Islands and the role of The University of the South Pacific'in MR Dakuidreketi and GI Lingram (eds), Higher Education and Community Engagement in the Pacific: Development and Policy Issues (University of the South Pacific Press, Suva 2014) 70-91. at p. 76.

$81 \quad$ Veitayaki and Manoa $\left(\mathrm{n}_{78}\right)$ at $\mathrm{p} 72$.

82 Veitayaki and South (n 54$)$. 


\section{Coordination for Implementation: A Regional Science and Technology Strategy?}

For capacity development and technology transfer to meet national and regional needs, those needs must first be identified. Losc Articles 266(2) provides that States shall promote the development of the marine scientific and technological capacity of States which may need and request technical assistance. Furthermore, LOsC Article 275(2) provides that States shall support the establishment and strengthening of national marine scientific and technological research centres so as to provide for advanced training facilities and necessary equipment, skills and know-how as well as technical experts to such States which may need and request assistance. This underscores the importance of enabling technology transfer needs to be identified and ensuring there are avenues through which assistance can be requested.

Although few Pacific Island Countries have articulated national marine scientific research policies, the Pacific Islands Regional Ocean Policy sets a vision to improve understanding of the ocean in three ways: identifying and meeting information needs; access to information; and science education and training. ${ }^{83}$ Strengthening the international framework for science and technology transfer and capacity development through the development of the ILBI would therefore align with these existing regional priorities.

However, fragmentation in regulatory and institutional frameworks for marine scientific research hinders the prioritisation of research needs in Pacific Island Countries. ${ }^{84}$ The development of a regional marine science and technology needs assessment could be useful to identify technology transfer and scientific capacity development priorities, including to benefit from marine genetic resources in ABNJ. Such a strategy could consider how to identify and meet the scientific capacity development needs of the region at international, institutional and individual levels. Existing regional arrangements such as the Council of Regional Organisations in the Pacific, ${ }^{85}$ which facilitates coordination between regional organisations engaged in science and technology, and

83 Pacific Islands Regional Ocean Policy (n 47).

84 Salpin (n 11).

85 Council of Regional Organisations in the Pacific comprises the heads of regional organisations in the Pacific, including USP, SPC and SPREP. http://www.forumsec.org/pages .cfm/about-us/our-partners/crop/?printerfriendly=true; accessed to September 2017. 
the Office of the Pacific Ocean Commissioner ${ }^{86}$ could be appropriate avenues to progress such a strategy. 87

\section{Towards an Enabling Environment for Technology Transfer?}

\section{An Integrated Approach to Acquire, Share and Apply Knowledge}

The development of the ILBI is an opportunity for States to strengthen the implementation of the LOSC framework provisions for technology transfer. Due to the different needs within and between regions, there will be no 'one size fits all' solution for technology transfer and capacity development. The development of the ILBI could, however, create an enabling international environment for scientific capacity development where different needs could be better identified and met. The acquisition, dissemination and application of scientific knowledge could be progressed through strengthened international marine science cooperation, technology transfer and capacity development (see Fig. 1).

The acquisition, dissemination and application of scientific knowledge are important in the context of ABNJ. The 1970 Declaration of Principles Governing the Sea-Bed and the Ocean Floor, and the Subsoil Thereof, Beyond the Limits of National Jurisdiction, ${ }^{88}$ for example, called on States to promote international cooperation in scientific research through: (a) participation in international

86 Office of the Pacific Ocean Commissioner; http://www.forumsec.org/pages.cfm/strategicpartnerships-coordination/pacific-oceanscape/pacific-ocean-commissioner.html; accessed 10 September 2017. See also Framework for a Pacific Oceanscape in C Pratt and H Govan, 'Our Sea of Islands, Our livelihoods, Our Oceania: Framework for a Pacific Oceanscape: a catalyst for implementation of ocean policy' (Report prepared for the Council of Regional Organisations of the Pacific Marine Sector Working Group, Suva, 2010), at p.59; available at http://www.forumsec.org/resources/uploads/embeds/file/ Oceanscape.pdf; accessed 1o September 2017.

87 For a discussion of the role of the Council of Regional Organisations in the Pacific and the Office of the Pacific Ocean Commissioner in regional coordination and cooperation see G Quirk and H Harden-Davies, 'Cooperation, Competence and Coherence: The Role of Regional Ocean Governance in the South West Pacific for the Conservation and Sustainable Use of Biodiversity beyond National Jurisdiction' (2017) 32(4) International Journal of Marine and Coastal Law, this special issue.

88 UNGA Resolution 25/2749, 'Declaration of Principles Governing the Sea-Bed and the Ocean Floor, and the Subsoil Thereof, Beyond the Limits of National Jurisdiction', 17 December 1970; available at https://documents-dds-ny.un.org/doc/RESOLUTION/GEN/NRo/35o/14/ IMG/NRo35014.pdf?OpenElement; accessed 11 September 2017. 


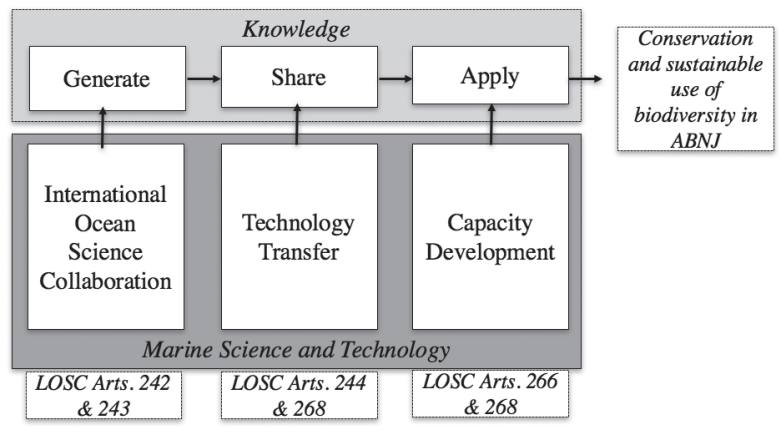

FIGURE 1 Three pillars to create an enabling international environment for scientific capacity development

programs including by encouraging participation of personnel from different countries; (b) publication of research programs and dissemination of results; (c) strengthening research capabilities. ${ }^{89}$ In 2015 and 2016, the UNGA recognised that realising benefits of the LOSC could be enhanced by international cooperation, technical assistance and capacity-building. ${ }^{90}$

An integrated approach to the acquisition, sharing and application of scientific knowledge could be particularly important to share benefits from marine genetic resources. The importance of technology transfer and international cooperation to build research and innovation capacity for 'adding value to genetic resources' for developing countries is recognised by the 2010 Nagoya Protocol on Access to Genetic Resources and the Fair and Equitable Sharing of Benefits Arising from Their Utilization to the Convention on Biological Diversity. ${ }^{91}$ The 2001 International Treaty on Plant Genetic Resources for Food and Agriculture ${ }^{92}$ (ITPGRFA) identifies information exchange, access to technology and capacity-building as forms of benefit sharing of genetic resources. ${ }^{93}$

\footnotetext{
$89 \quad$ Ibid., at para 10.

9o UNGA (n 9).

91 Nagoya Protocol on Access to Genetic Resources and the Fair and Equitable Sharing of Benefits Arising from Their Utilization to the Convention on Biological Diversity (Nagoya, 29 October 2010, in force 12 October 2014) at Preamble; available at https://treaties.un.org/ pages $/$ ViewDetails.aspx?src=TREATY\&mtdsg_no=XXVII-8-b\&chapter=27\&lang=en; accessed 10 September 2017; Convention on Biological Diversity (Rio de Janeiro, 5 June 1992, in force 29 December 1993) 176o UNTS 79. Arts. 16, 19.

92 International Treaty on Plant Genetic Resources for Food and Agriculture (Rome, 3 November 2001, in force 29 June 2004) 2400 UNTS 303.

93 ITPGRFA Art. 13.1.
} 
This notion that sharing benefits from marine genetic resources can be progressed through scientific investigation, technology transfer and capacity development is pertinent to the development of the ILBI, as illustrated in the discussion of Pacific Island Countries. The ITPGRFA calls on Parties to cooperate to "promote an integrated approach to exploration, conservation and sustainable use [of genetic resources]"94 including through surveys, collection of samples and associated information and metadata. The merit of an integrated approach is also reflected in UNGA Resolution 69/292, which states that the elements of the ILBI should be considered "together and as a whole". An integrated approach to the investigation, conservation and sustainable use of marine genetic resources in ABNJ could foster potential 'spill-over' benefits whereby technology could be applied for sustainable development purposes that go beyond biodiversity in ABNJ.

\section{Acquiring Scientific Knowledge: International Collaboration for Regional Participation}

International cooperation is crucial to enhance scientific knowledge of marine biodiversity in $\mathrm{ABNJ}$, especially in regions with low marine research capacity. The ILBI could seek to strengthen the implementation of LOSC Articles 242 and 243 through international cooperation in marine scientific research in order to advance knowledge of biodiversity in $\mathrm{ABNJ}$ and increase participation of scientists from developing countries.

Increasing scientific knowledge of biodiversity in $\mathrm{ABNJ}$ would require sustained support for existing initiatives, as well as resources for new investigations. The development of new observation technologies and understanding of the roles and functions of biodiversity in $\mathrm{ABNJ}$, and the transfer of marine technology to share knowledge and enhance capacity of siDs are among the aims of the 'International Decade of Ocean Science' proposed by the Ioc. ${ }^{95}$ This illustrates international recognition of the need to enhance international marine science cooperation for sids. The International Indian Ocean Expedition, ${ }^{96}$ organised under the auspices of IOC, is an example of internationally collaborative, regionally coordinated research. Similarly, to fill gaps in

\footnotetext{
94 ITPGRFA Art. 5.1.

95 Unesco-IOc. 2017. One Planet One Ocean. Proposal for an International Decade of Ocean Science for Sustainable Development (2021-2030) at p. 1. Available at http://www .unesco.org/new/fileadmin/MULTIMEDIA/HQ/SC/pdf/Ioc_Decade-Ocean-Science_ Handout_Final.pdf; accessed 28 February 2017.

96 Second International Indian Ocean Expedition 2015-2020, http://www.iioe-2.incois.gov.in/; accessed 10 September 2017.
} 
scientific knowledge of biodiversity in Pacific ABNJ, an 'International South Pacific Ocean Investigation' could be considered. This could aim to galvanise political will to increase scientific knowledge of biodiversity beyond national jurisdiction, develop research capacity and transfer technology. IOC, perhaps through IOC-WESTPAC, could facilitate cooperation between Pacific Island Countries and nations with stronger research capacity active in the region, such as Japan, Korea, Australia, New Zealand, USA, France and UK. However, this would be entirely dependent on resources to support research activities.

\section{Disseminating Scientific Knowledge: Data and Knowledge Exchange}

Access to data and knowledge will be crucial to enable technology transfer and implement the ILBI. Global science increasingly supports open data; for example, an international accord published in 2015 by Science International stated that "open data should be the default position for publicly funded science" and updating historical values for "a new era of technology" is essential to achieve full benefit to society. ${ }^{97}$ The obligation to publish and share data and knowledge enshrined in Losc Article 244 could be further implemented under the ILBI.

The United Nations Agreement for the Implementation of the Provisions of the United Nations Convention on the Law of the Sea of 10 December 1982 Relating to the Conservation and Management of Straddling Fish Stocks and Highly Migratory Fish Stocks ${ }^{98}$ (UNFSA) offers an example of how this can be achieved by elaborating provisions and standards for the collection and sharing of data. For example, UNFSA Article 14 provides for the collection and exchange of scientific data, ${ }^{99}$ international cooperation in research, scientific capacity development in line with a set of standard requirements for the collection and sharing of data as elaborated in UnfSA Annex I. Similarly, an elaboration of data-sharing principles, standards and requirements could be included in the ILBI to implement the LOSC obligation to publish and disseminate data. International standards and best-practice guidelines for data management and informatics provide a basis which the development of the ILBI could draw from.

\footnotetext{
97 Science International, "Open Data in a Big Data World" (2015) at p. 3. Available at http:// www.science-international.org/; accessed 22 September 2016.

98 United Nations Agreement for the Implementation of the Provisions of the United Nations Convention on the Law of the Sea of 10 December 1982 Relating to the Conservation and Management of Straddling Fish Stocks and Highly Migratory Fish Stocks (New York, 4 December 1995, in force 11 December 2001) 2167 UNTS 3. 


\section{Applying Scientific Knowledge: Capacity Development}

Institutions: A Global Network of Regional Marine Science,

Technology and Innovation Clusters

Regional marine science and technology centres could increase absorptive capacity, provide a hub for technology and research infrastructure and a focal point for regional research and engagement. The ILB I could reinforce the need to develop a global network of regional and national marine science, technology and innovation clusters. Linking regional centres via a virtual global network could support the participation of developing countries in international research collaborations. Existing models highlight the importance of training courses, workshops, lecturer exchanges, visiting professorships and post-graduate teaching programs. ${ }^{100}$

This also illustrates the advantages of intergovernmental coordination to aid international and regional cohesion. Stronger coordination with competent international organisations, such as the IOC, as stipulated in Article 276 of the Losc, could support the development of an internationally connected regional network of marine science and technology centres. The ITPGRFA recognises a role for International Agricultural Research Centres of the Consultative Group on International Agricultural Research (CGIAR) in making samples available as part of the multilateral system of access and benefit sharing. ${ }^{101}$ This offers an example of how international research arrangements could be integrated into the ILBI.

Individuals: Training and Skill Development

Scientific research skills and training are an important priority for developing human capacity to participate in the conservation and sustainable use of biodiversity in ABNJ. The LOSC obligation under Article 266 to promote the development of marine scientific and technological capacity could be further implemented under the ILBI by providing opportunities for scientific training and education and enabling the implementation of Article 269 (e.g., researcher exchanges ${ }^{102}$ and joint international scientific research programs) ${ }^{103}$

Long-term collaborations could be supported by a mentoring scheme linking early career researchers in developing countries with senior scientists in developed countries facilitated through existing international scientific networks. Workshops and training courses targeted to ABNJ research could be

\footnotetext{
100 IOC-WESTPAC (n 69).

101 ITPGRFA Arts. 11.5, 15.1.

102 LOsC Art. 269(d).

103 LOsC Art. 269(e).
} 
delivered through a variety of means: in person; facilitated by regional networks such as IOC and its regional commissions and training centres; or online, such as Ioc Ocean Teacher Global Academy. Researcher training opportunities, from undergraduate to Ph.D. level and beyond, could be facilitated through regional centres and international scientific networks. However, to attract to and retain researchers at regional science and technology centres, it will be necessary to increase absorptive capacity through, for example, teacher exchanges, continuous professional development opportunities and incentives, such as sustained international collaborations and resources.

\section{Challenges Ahead}

A number of challenges relating to technology transfer and capacity development remain for the development of the ILBI. In particular, the scope of technology transfer will need to be understood and agreed, and implementation options established.

\section{Clearinghouse}

A clearinghouse mechanism has been proposed as a means to provide a centralised portal to access and exchange information on activities related to biodiversity in $\mathrm{ABNJ}^{104}$ and promote international collaboration. This could facilitate technology transfer by improving linkages between technology recipients and donors, and enabling knowledge exchange. Questions remain, however, on the types of information that would be included and how it could be managed. A clearinghouse would require sustained resources and stakeholder engagement (especially from scientific communities) to ensure that quality information was made available to users. Building on the strengths of existing mechanisms, such as the Ocean Biogeographic Information System of the IOC, would be important.

However, the capacity constraints of siDs, illustrated in Pacific Island Countries, mean that web-based clearinghouses could be quite limited in effect without corresponding capacity development and technical infrastructure.

\section{Scope}

The development of the ILBI will consider "capacity building and technology transfer" as it relates to the conservation and sustainable use of biodiversity in ABNJ. However, technology and capacity building for ABNJ cannot be considered in isolation, as it could be equally applicable in areas within national jurisdiction. Furthermore, technology can have multiple applications; for

104 See for example PSIDS (n 12); AOSIS (n 12); and EU (n 44) at paras 13 and 14. 
example, technology required for marine genetic resources research could also be useful for area-based management or even broader purposes.

Fostering a broad scope of technology transfer, including technologies that can be used for multiple purposes, could support meaningful capacity development. A broad scope of technology under the ILBI could be the best option to ensure efficiency and effectiveness of research efforts. However, a balance between specificity and flexibility to support effective implementation will be needed. Promoting technology development, as well as transfer, into the scope of the ILBI will be important, to facilitate investigation of biodiversity in ABNJ and advance scientific knowledge to support conservation and sustainable use. However, although LOSC Part XIV concerns the "development and transfer of marine technology"105 (emphasis added), UNGA Resolution 69/292 refers only to "transfer of technology". 106

A holistic scope of technology-transfer development could reduce duplication of activities and resources, and have wider advantages for sustainable development. The importance of technology transfer and capacity development in marine scientific research for sustainable development is recognised in UNGA Resolutions ${ }^{107}$ and in Sustainable Development Goal 14. Marine scientific research is an important ingredient for sustainable development for sIDS, in a range of areas including marine genetic resources, fisheries and minerals. ${ }^{108}$ The potential for the ILBI to strengthen capacity development in pursuit of sustainable development has been recognised by New Zealand, ${ }^{109}$ Australia ${ }^{110}$ and the European Union (EU). ${ }^{111}$ Although the ILBI cannot function as an overarching implementing instrument for Part XIV as a whole, it does provide a

\footnotetext{
105 LOSC Art. 268(b) calls on States to promote the development of marine technology.

106 UNGA (n 1) at p. 1, para 2.

107 UNGA Res A/71.L.26 at [247] (n 9).

108 Salpin (n 11).

109 New Zealand, 2016, "Preparatory Committee on Conservation and Sustainable Use of Marine Biological Diversity of Areas Beyond National Jurisdiction, New Zealand Submission, December 2016". Available at: http://www.un.org/depts/los/biodiversity/ prepcom_files/rolling_comp/New_Zealand.pdf; accessed 14 February 2017, at p. 8.

110 Australia, 2016, 'Preparatory Committee on Conservation and Sustainable Use of Marine Biological Diversity of Areas Beyond National jurisdiction (BBNJ). Submission by Australia. December 2016'. Australian Mission to the United Nations, New York, 6 December 2016. 'Australia: "capacity building can assist developing country partners to engage, consistent with SDG Goal 14, in the conservation and sustainable use of the oceans, seas and maritime resources'. Available at http://www.un.org/depts/los/biodiversity/ prepcom_files/rolling_comp/Australia.pdf; accessed 14 February 2017, at p. 8.

111 EU (n 44).
} 
substantial opportunity to strengthen the international framework for scientific capacity development.

\section{Funding}

Sustained funding will be crucial for technology transfer and capacity development, including to generate, share and apply knowledge from ABNJ. International collaboration will be crucial to advance knowledge of biodiversity in ABNJ given the high cost of conducting marine scientific research in deep and remote open ocean ABNJ, especially in the Southern Hemisphere. AOSIS and PSIDs have suggested including a fund with a specific allocation for capacity development, technology transfer and scholarship in sIDs. ${ }^{112}$

However, it is unclear whether a financial mechanism will be established under the ILBI. The Global Environment Fund (GEF), Unesco-IOC Capacity Development Fund and the Addis Ababa Action Agenda technology and facilitation fund could provide examples for funding capacity development and technology transfer. Furthermore, the agencies identified in the 'Resolution on the development of national marine science, technology and ocean service infrastructures' could also provide examples: "World Bank, the regional banks, the United Nations Development Programme, the United Nations Financing System for Science and Technology and other multilateral funding agencies". ${ }^{113}$ New mechanisms, such as an "Ocean Sustainability Bank" and innovative blue finance partnerships have also been proposed. ${ }^{114}$ Coordination and ease of application will be a crucial priority to ensure that SIDS can access funding opportunities. Many developing States, including sIDS, call for a non-voluntary or binding mechanism, ${ }^{115}$ others call for a mixture of voluntary and mandatory measures. ${ }^{116}$ On the other hand, the $\mathrm{EU}^{117}$ and various developed nations favour voluntary measures. The question of whether technology transfer should be voluntary or mandatory under the ILBI remains unanswered.

\footnotetext{
112 PSIDS (n 12).

113 'Resolution on the development of national marine science, technology and ocean service infrastructures' ( $\mathrm{n}_{5}$ ).

114 T Thiele and H Harden-Davies (2016), "Technology Transfer". Nereus Policy Briefs. Available at http://www.nereusprogram.org/policy-brief-bbnj-technology-transfer/; accessed 14January 2017 .

115 See for example FSM (n 8).

116 Fiji, 2016, "Fiji's submission for BBNJ PrepCom" at p. 4, http://www.un.org/depts/los/ biodiversity/prepcom_files/rolling_comp/Fiji.pdf; accessed 14 February 2017.

117 EU (n 44).
} 


\section{Conclusion}

Marine technology transfer and scientific capacity development are crucial for the conservation and sustainable use of biodiversity in ABNJ. The LOSC framework for technology transfer is strongly interlinked with scientific capacity development and emphasises the acquisition, evaluation and dissemination of marine scientific and technological knowledge, information and data. However, gaps and ambiguities weaken this framework. The development of the ILBI is an opportunity to strengthen the implementation of Part XIV of the LOsc and foster a new paradigm of technology transfer and innovation based on knowledge exchange, open data and scientific capacity development.

Improving the international framework for technology transfer and capacity development could also advance regional objectives for Pacific Island Countries and have broader sustainable development benefits. The institutional, technological, financial and human capacity constraints that limit the ability of Pacific Island Countries to engage in scientific research involving marine genetic resources in $\mathrm{ABNJ}$ illustrate the need to increase technology transfer and develop scientific capacity in the region, at institutional and individual levels. These are already identified as broad priorities for the region; however, the development of a Pacific Islands regional marine science and technology strategy could enable clearer identification of technology transfer and scientific capacity development needs. Enhancing the capacity of existing regional organisations in strengthening international links could help achieve a well-resourced and cooperative network of marine science and technology centres, providing hubs for research infrastructure and focal points for science and skills.

An integrated approach to the investigation, conservation and sustainable use of biodiversity in order to promote the acquisition, dissemination and application of scientific knowledge could provide a useful focus for the development of technology transfer under an ILBI. Based on lessons from Pacific Island Countries, this could enhance the international framework for technology transfer through: sustained support for sharing of global marine scientific data and information; strengthened links between research institutions to form a global network of regional marine science and technology clusters; and increased skill development opportunities, including distance learning and workshops. A broad scope of technology, including multi-purpose technologies, could enable meaningful capacity development. However, a number of questions remain in relation to the scope and implementation of technology transfer. International cooperation, at the global and regional level, will continue to play a crucial role to secure the required resources for implementation, avoid duplication and ensure that technology transfer meets identified needs. 